Assiut University web-site: www.aun.edu.eg

\title{
EFFECT OF LEVEL AND TIME OF L-ARGININE ADDITION TO SEMEN EXTENDER ON THE FREEZABILITY AND FERTILIZING POTENTIALS OF BUFFALO SPERMATOZOA
}

\author{
BADR, M.R. ${ }^{1}$, ABDEL-KHALEK E. ABDEL-KHALEK ${ }^{2}$, SAKR, A.M ${ }^{3}$, \\ HEGAZY, M.M. ${ }^{3}$ and RAWASH, Z.M. ${ }^{1}$ \\ ${ }^{1}$ Artificial Insemination and Embryo Transfer Department, Animal Reproduction Research Institute, \\ Giza, Egypt. \\ ${ }^{2}$ Department of Animal Production, Faculty of Agriculture, Mansoura University, Mansoura, 35516, \\ Egypt \\ ${ }^{3}$ Animal Production Research Institute, Giza, Egypt.
}

Received: 7 July 2020; Accepted: 18 August 2020

\begin{abstract}
The objective of this study was to investigate the profit of L-arginine addition to the freezing extender on freezability, lipid peroxidation, and fertilizing potentials of frozen-thawed buffalo spermatozoa. Semen was collected with artificial vagina from five adult fertile bulls and diluted with Tris-base extender containing different $\mathrm{L}$-arginine concentrations $(0,0.5,1,5$ and $10 \mathrm{mM}$ ) added during the dilution or after equilibration for $2 \mathrm{~h}$. Diluted semen was cooled to $4^{\circ} \mathrm{C}$ throughout one hour, equilibrated for $2 \mathrm{~h}$ and then frozen in $0.25 \mathrm{ml}$ straws, prior to be stored in liquid nitrogen. Cryopreserved spermatozoa were assessed for post-thawing sperm motility, viability index, acrosomal integrity, lipid peroxidation and fertility rate. The current results clearly indicated that adding $0.5 \mathrm{mM} \mathrm{L}$ - arginine to the freezing extender after the equilibration period significantly $(\mathrm{P}<0.05)$ improved post-thawing motility, viability index and maintain acrosomal integrity $(61.66 \pm 10.14 \%, 130.83 \pm 9.62$ and $19.33 \pm 4.82 \%$, respectively) compared with the control semen $(33.33 \pm 4.40 \%, 88.33 \pm 11.03$ and $33.67 \pm 3.28 \%$, respectively). Moreover, addition of $0.5 \mathrm{mM} \mathrm{L}$ - arginine to the freezing extender after equilibration period significantly diminished $(\mathrm{P}<0.05)$ lipid peroxidation $\left(11.33 \pm 3.28 \mathrm{nmol} / 10^{9}\right)$ compared with the control $\left(26.67 \pm 3.18 \mathrm{nmol} / 10^{9}\right)$. All of these previously enhanced semen characteristics were reflected positively on its fertilizing potentials. The present results revealed that addition of $0.5 \mathrm{mM} \mathrm{L}$ - arginine to the freezing extender after $2 \mathrm{~h}$ equilibration (short time exposure) might improve semen quality, preserve the fertilizing potentials and reduce cryodamage of the buffalo spermatozoa.
\end{abstract}

Keywords: L-arginine, buffalo, spermatozoa, cryopreservation, lipid peroxidation

\section{INTRODUCTION}

Artificial insemination technology has been developed in Egypt

Corresponding author: HEGAZY, M.M.

E-mail address: mmgad2120@gmail.com

Present address: Animal Production Research Institute, Giza, Egypt. with excellent results, especially in dairy cows. However, the application of this technology in the buffalo is still minimal. The application of AI has been shown to have the ability to distribute genes from fabulous genetic males for improving productive performance (El-Sheshtawy et al., 2015). Cryopreservation induces adverse effects on the spermatozoa that may 
result in decreasing the percentage of intact spermatozoa, viability rate, structural integrity, or loss of motility and fertilizing capacity (Medeiros et al., 2002). Mammalian spermatozoa have very specific lipid composition and a high ratio of polyunsaturated fatty acids. Oxidative stress can cause lipid peroxidation of the sperm membrane which may cause severe functional disorders of sperm (Sanocka and Kurpisz, 2004). These peroxides constitute a potential hazard to the structural and functional integrity of spermatozoa, lessening the motility and metabolic activity of cells that are aging either within the reproductive tract in vivo or during storage in vitro (Mann and Lutwak-Mann, 1981).

L-arginine (2-Amino-5-guanidinopentanoic acid) plays a key role in modulating host defenses and cellular immunity. It actively participates in sperm formation (Adman, 1970). L-arginine plays an important role in stimulating sperm motility in rabbits (Radany et al., 1981), humans (Aydin et al., 1995) and goats (Patel et al., 1998) under in vitro conditions. A deficiency in L-arginine causes derangement of sperm metabolism leading to decrease in motility and loss of spermatogenesis (Srivastava et al., 2006). L-arginine prevents membrane lipid peroxidation in spermatozoa under different peroxidation conditions (Srivastava et al., 2006). It has been proposed that the beneficial effects of L-arginine are linked to nitric oxide (NO) (Chemineau et al., 1991). NO is a short-lived free radical, synthesized in many mammalian cell types by a class of NADPH dependent enzymes called nitric oxide synthases (NOS). These enzymes catalyze the conversion of L-arginine to Lcitrulline and NO (Moncada et al., 1992). It has showen that L-arginine reported to have a positive effect on improving the rate of glycolysis, resulting in higher rates of ATP and lactate generation in spermatozoa (Aydin et al., 1995). It participates in synthesis of some hormones (insulin, prolactin, glucagon, growth hormone) as well as biosynthesis of creatine, agmatine, glutamate, proline and polyamines and in the structure of anti-diuretic hormone (ADH) (Soeters et al., 2002).

Therefore, this study was conducted to determine the optimal level and time of adding L-arginine to buffalo semen extender to obtain high freezability and fertilizing ability after cryopreservation.

\section{MATERIALS AND METHODS}

\section{Farm management and semen collection}

This study was carried out at the Artificial Insemination and Embryo Transfer Department, Animal Reproduction Research Institute, and Animal Production Research Institute. Five sexually mature healthy buffalo bulls, ranging 3-4 years old age and 420-450 kg live body weight. Bulls were housed individually in pens and kept at the Animal Reproduction Research Institute farm (Cairo, Egypt) and fed on balanced ration.

Two consecutive ejaculates were collected from each bull weekly for successive six weeks using an artificial vagina $\left(42^{\circ} \mathrm{C}\right)$. Immediately after collection, ejaculates with at least $70 \%$ motility and $>85 \%$ normal sperm morphology were pooled to eliminate individual differences. The pooled semen was split into five equal aliquots for processing according to treatments.

\section{Sperm processing and stress treatment before cryopreservation}

Aliquots of ejaculate were diluted at room temperature with Tris-based extender (Trisegg yolk extender $(20 \%$ EY) containing 20 $\mathrm{ml}$ of egg yolk, 3.025gTris (hydroxyl methyl amino methane), $1.675 \mathrm{~g}$ citric acid, $0.75 \mathrm{~g}$ glucose, $7 \mathrm{ml}$ glycerol, $0.25 \mathrm{gm}$ lincomycin, $0.005 \mathrm{gm}$ streptomycin and completed with up to $100 \mathrm{ml}$ bidistilled 
water) in the extender we use glycerol as cryoprotectant with concentrate $7 \%$ add to extender at room temperature $37{ }^{\circ} \mathrm{C}$ before cooling. The extender contained different levels of L-arginine (L-Argnine $99 \%$, Jahangir villa, Mumbai -400005 India) (0, $0.5,1,5$ and $10 \mathrm{mM}$ ) according to (ALEbady et al., 2012; Keya et al., 2017 and Abd-Allah et al., 2019). Semen was diluted at a rate of 1:8, and the diluted semen with each L-arginine level and control group were subjected to gradual cooling from 37 ${ }^{\circ} \mathrm{C}$ to $5{ }^{\circ} \mathrm{C}$ throughout $60 \mathrm{~min}$ in a cold cabinet and equilibrated at $4^{\circ} \mathrm{C}$ for $2 \mathrm{~h}$. The cooled semen samples were subsequently were loaded into $0.25 \mathrm{ml}$ French straws (IMV, L'Aigle, France), and sealed thermally. These straws were placed horizontally $6 \mathrm{~cm}$ above the liquid nitrogen surface where the temperature was approximately $-120^{\circ} \mathrm{C}$. After $15 \mathrm{~min}$, they were immersed directly into liquid nitrogen $\left(-196^{\circ} \mathrm{C}\right)$ for storage. The straws were stored at least for 24 hour before evaluation.

\section{Experiment design:}

1 -Tris-based extender was supplemented with different levels of L-arginine (0. 0.5, 1 , 5 and $10 \mathrm{mM}$ ) at $37^{\circ} \mathrm{C}$, then the diluted semen was subjected to gradual cooling from $37{ }^{\circ} \mathrm{C}$ to $5{ }^{\circ} \mathrm{C}$ throughout $60 \mathrm{~min}$ in a cold cabinet. The cooled semen was equilibrated at $4{ }^{\circ} \mathrm{C}$ for $2 \mathrm{~h}$. Frozen semen was thawed at $37{ }^{\circ} \mathrm{C}$ for $30 \mathrm{~s}$ to study the effect of adding different L-arginine levels to Tris-based extender during dilution process on freezability of buffalo spermatozoa in post-thawed semen.

2 - Tris-based extender extender was supplemented with different levels of $\mathrm{L}$ arginine $(0,0.5,1,5$ and $10 \mathrm{mM})$ for $2 \mathrm{~h}$ equilibration at $4^{\circ} \mathrm{C}$, then the equilibrated semen was frozen.
Post-thawing evaluation of sperm parameters

Post-thawing progressive sperm motility: viability index and acrosomal integrity were assessed according to Badr et al. (2010).

Lipid peroxidation of post-thawed semen

The concentrations of Malondialdehyde (MDA), as a marker of LPO in the postthawed semen supplemented with Larginine at dilution or after equilibration, were measured according to the method of Kumaresan et al. (2009). The MDA concentrations were read at $532 \mathrm{~nm}$ and expressed in $\mathrm{nmol} / 10^{9}$.

\section{Fertility trial}

A total of 128 buffalo cows synchronized to estrus (Hoque et al., 2011) were used in fertility trails. In brief, buffalo cows were i.m. injected with $5 \mathrm{ml} \mathrm{Receptal/} \mathrm{buffalo}$ on day 0, $2 \mathrm{ml}$ Estrumate /buffalo on day 9, and $5 \mathrm{ml} \mathrm{Receptal/} \mathrm{buffalo} \mathrm{on} \mathrm{day} \mathrm{9:} \mathrm{and}$ artificially inseminated on day 10 by using frozen-thawed straw from control and the best semen diluted with L- arginine. Each female was inseminated with a single straw $12 \mathrm{~h}$ after start of estrous behavior, using recto-vaginal technique and the universal insemination gun. The frozen-thawed spermatozoa were deposited in the uterine body. Conception rate was confirmed by rectal palpation at least 45 days after insemination.

\section{Statistical analysis}

All data were analyzed by using Costat Computer Program (1986), Version 3.03 copyright Cottort Software, using one way ANOVA analysis. The results were expressed as means $\pm \mathrm{SE}$. The significant differences among mean of treatments were tested using Duncan's multiple range test (Duncan, 1955), when the F-value reveals significant differences at $\mathrm{P}<0.05$. 


\section{RESULTS}

\section{Effect of adding L-arginine at dilution on} sperm freezability

Results presented in Table 1 revealed that, addition of L-arginine only at a level of $1 \mathrm{mM}$ to the freezing extender resulted in significant $\quad(\mathrm{P}<0.05) \quad$ improvement in percentage of progressive motility and viability index of cryopreserved buffalo semen as compared to control. It is of interest to observe that the most motile spermatozoa were in circular movement.

Table 1: Freezability of buffalo spermatozoa as affected by L- arginine addition to semen extender at dilution

\begin{tabular}{lccc}
\hline Treatment & $\begin{array}{c}\text { Progressive } \\
\text { motility }(\%)\end{array}$ & $\begin{array}{c}\text { Viability } \\
\text { index }\end{array}$ & $\begin{array}{c}\text { Acrosomal abnormality } \\
(\%)\end{array}$ \\
\hline Control & $33.33 \pm 7.27^{\mathrm{b}}$ & $69.17 \pm 23.22^{\mathrm{ab}}$ & $29.33 \pm 4.49$ \\
\hline L-arnginine $(0.5 \mathrm{mM})$ & $48.33 \pm 4.41^{\mathrm{ab}}$ & $86.67 \pm 11.68^{\mathrm{ab}}$ & $28.66 \pm 5.93$ \\
\hline L-arnginine $(1 \mathrm{mM})$ & $60.00 \pm 8.67^{\mathrm{a}}$ & $106.67 \pm 13.65^{\mathrm{a}}$ & $22.33 \pm 2.91$ \\
\hline L-arnginine $(5 \mathrm{mM})$ & $38.33 \pm 6.02^{\mathrm{b}}$ & $71.67 \pm 13.03^{\mathrm{ab}}$ & $32.33 \pm 3.84$ \\
\hline L-arnginine $(10 \mathrm{mM})$ & $28.33 . \pm 4.41^{\mathrm{b}}$ & $44.17 \pm 7.13^{\mathrm{c}}$ & $37.33 \pm 3.18$ \\
\hline
\end{tabular}

Values with different superscripts within the same column differ significantly at $\mathrm{P}<0.05$.

Additionally, the present results showed that there was no significant difference in the percentage of acrosomal integrity between L-arginine concentrations and control semen when L-arginine was added to the freezing extender from the beginning of dilution at $37^{\circ} \mathrm{C}$.

Effect of adding L-arginine postequilibration on sperm freezability

Data in Table 2 indicated that, L-arginine addition to the freezing extender postequilibration at a level of $0.5 \mathrm{mM}$ appeared to have an quick effect on the quality of buffalo semen freezability, in terms of significant $(\mathrm{P}<0.05)$ augment in buffalo semen post-thawing progressive motility, viability index and reducing acrosomal integrity compared with the control semen. On the other hand, increasing level of Larginine to $10 \mathrm{mM}$ had a drastic effect $(\mathrm{P}<0.05)$ on post-thawing sperm motility, and the acrosomal integrity of the cryopreserved buffalo spermatozoa did not differ than in control group. However, viability index was significantly $(p<0.05)$ lower than in control group by increase Largnine level to $10 \mathrm{mM}$. 
Table 2: Freezability of buffalo spermatozoa as affected by L- arginine addition to semen extender after $2 \mathrm{~h}$ of equilibration.

\begin{tabular}{llll}
\hline Treatment & $\begin{array}{l}\text { Progressive } \\
\text { motility (\%) }\end{array}$ & Viability index & $\begin{array}{c}\text { Acrosomal } \\
\text { abnormality (\%) }\end{array}$ \\
\hline Control & $33.33 \pm 4.40^{\mathrm{bc}}$ & $88.33 \pm 11.03^{\mathrm{b}}$ & $33.67 \pm 3.28^{\mathrm{a}}$ \\
\hline L-arnginine $(0.5 \mathrm{mM})$ & $61 . .66 \pm 10.14^{\mathrm{a}}$ & $130.83 \pm 9.62^{\mathrm{a}}$ & $19.33 \pm 4.82^{\mathrm{b}}$ \\
\hline L-arnginine $(1 \mathrm{mM})$ & $48.33 \pm 7.27^{\mathrm{ab}}$ & $105.83 \pm 11.22^{\mathrm{ab}}$ & $26.33 \pm 4.34^{\mathrm{ab}}$ \\
\hline L-arnginine $(5 \mathrm{mM})$ & $38.33 \pm 7.27^{\mathrm{abc}}$ & $79.16 \pm 16.87^{\mathrm{bc}}$ & $28.33 \pm 2.73^{\mathrm{ab}}$ \\
\hline L-arnginine $(10 \mathrm{mM})$ & $23.33 . \pm 6.01^{\mathrm{c}}$ & $49.83 \pm 3.83^{\mathrm{c}}$ & $35.00 \pm 3.06^{\mathrm{a}}$ \\
\hline
\end{tabular}

Values with different superscripts within the same column differ significantly at $\mathrm{P}<0.05$.

Effect of L- arginine addition to semen extender on lipid peroxidation of the cryopreserved buffalo spermatozoa.

Data regarding the effect of L- arginine addition to the freezing extender (at dilution or post-equilibration) on malondialdehyde (MDA) as a lipid peroxidation marker in cryopreserved buffalo spermatozoa (Table 3) revealed that adding L-arginine at a level of $1 \mathrm{mM}$ at dilution and $0.5 \mathrm{mM}$ after $2 \mathrm{~h}$ of equilibration significantly $\quad(\mathrm{P}<0.05)$ diminished level of MDA in post-thawed semen to the minimum values as compared to their controls. Moreover, the current data indicated that increasing level of Larginine to the semen extender to $10 \mathrm{mM}$ had a severe effect on lipid peroxidation of the frozen-thawed buffalo spermatozoa.

Table 3: Malondialdehyde level as affected by time and level of L-arginine addition to semen extender of cryopreserved buffalo semen.

Malondialdehyde (nmol/109 sperm cells)

Treatment

\begin{tabular}{ccc} 
& at dilution & 2 h post-equilibration \\
\hline Control & $23.66 \pm 4.41 \mathrm{ab}$ & $26.67 \pm 3.18 \mathrm{ab}$ \\
\hline $\mathrm{L}$-arnginine $(0.5 \mathrm{mM})$ & $17.67 \pm 3.18 \mathrm{bc}$ & $11.33 \pm 3.28 \mathrm{c}$ \\
\hline $\mathrm{L}$-arnginine $(1 \mathrm{mM})$ & $11.67 \pm 3.67 \mathrm{c}$ & $19.67 \pm 2.34 \mathrm{bc}$ \\
\hline $\mathrm{L}-\operatorname{arnginine}(5 \mathrm{mM})$ & $20.33 \pm 2.34 \mathrm{abc}$ & $25.33 \pm 3.39 \mathrm{ab}$ \\
\hline $\mathrm{L}-\operatorname{arnginine}(10 \mathrm{mM})$ & $29.00 \pm 2.09^{\mathrm{a}}$ & $31.67 \pm 2.60^{\mathrm{a}}$
\end{tabular}

Values with different superscript in the same column are significantly different at $\mathrm{P}<0.05$. 


\section{Fertility trail}

The concentration of $1 \mathrm{mM}$ of L-arginine was used in a fertility experiment because it was the highest treatment in the progressive motility after dilution and before equilibration (Table 1). Also, Treatment of $1 \mathrm{mM} \mathrm{L}$ - arginine is considered the second best treatment after equilibration and dissolution after a $0.5 \mathrm{mM}$ of 1 arginine, so it was used in the fertility experiment to decide which the best treatments that can be used in diluents.

Conception rate was significantly $(\mathrm{P}<0.05)$ higher following artificial insemination of the synchronized buffaloes with frozen- thawed semen supplemented with $0.5 \mathrm{mM}$ L-arginine after $2 \mathrm{~h}$ of equilibration $(68.33 \pm 2.55 \%)$ compared with the control semen $(29.72 \pm 6.58 \%)$. However, conception rate was insignificantly higher for buffaloes inseminated by semen supplemented with $1 \mathrm{mM}$ L-arginine added from the beginning of dilution and the control semen $(44.44 \pm 12.11 \quad v s$ $29.7 \pm 6.58 \%$, respectively, Table 4) and insignificantly lower than semen supplemented with $0.5 \mathrm{mM}$ L-arginine after $2 \mathrm{~h}$ of equlipratiotion $(68.33 \pm 2.55 \%$, table $4)$.

Table 4: Conception rate of buffalo cows following artificial insemination with semen extended with L-arginine.

\begin{tabular}{lccc}
\hline \multicolumn{1}{c}{ Treatment } & $\begin{array}{c}\text { Inseminated } \\
\text { buffaloes (n) }\end{array}$ & $\begin{array}{c}\text { Conceived } \\
\text { buffaloes (n) }\end{array}$ & $\begin{array}{c}\text { Conception } \\
\text { rate }\end{array}$ \\
\hline Control & 42 & 14 & $29.7 \pm 6.58 \mathrm{~b}$ \\
\hline L-arnginine $(1 \mathrm{mM})$ at dilution & 39 & 18 & $44.4 \pm 12.11 \mathrm{ab}$ \\
\hline L-arnginine $(0.5 \mathrm{mM})$ post-equilibration & 47 & 32 & $68.3 \pm 2.55 \mathrm{a}$ \\
\hline
\end{tabular}

Values with different superscript in the same column are significantly different at $\mathrm{P}<0.05$.

\section{DISCUSSION}

The present study indicated that, supplementation of the freezing extender with L- arginine was significantly amplified the characteristics of the cryopreserved buffalo spermatozoa, such as progressive motility, viability, acrosomal integrity, reduced lipid peroxidation and preserve the fertilizing potential of the cryopreserved spermatozoa, depending on the dose and time of addition to the semen extender. These results are in line with the findings of several authors (Al-Ebady et al., 2012: Abd-Allah et al., 2019: Susilowati et al.,
2019). The previous authors reported positive effects of L-arginine on motility, antioxidant activity and membrane integrity of mammalian spermatozoa.

The current data revealed that the effect of L- arginine on post-thawed semen quality and fertilizing potential differed significantly according to the time of adding L-arginine to the freezing extender. Addition of L-arginine during the diluation at $37^{\circ} \mathrm{C}$ had no effect on semen viability or acrosomal integrity, but there were positive significant effect when add L-arginine with a concentration $1 \mathrm{mmol} / \mathrm{ml}$ on sperm 
viability. These results are in agreement with the result of O'Flaherty et al. (2004) and Öztürk et al. (2017), who found that the percentage of acrosome integrity and viability of spermatozoa did not varied significantly with addition of L-arginine to semen extender. These results may be due to L- arginine enhances c-GMP synthesis thus leading to an enhancement of the metabolic rate. It also enhances the $\mathrm{Ca}$ level in the mitochondria, generating a higher ATP level. These two effects lead to over increased sperm motility (Revelli et al., 2001) and play an important role in sperm hyperactivation and acrosomal reaction in vitro (Sliwa and Stochmal 2000). These results are equivalent with the current study that recorded increased circular movement of spermatozoa treated with L- arginine form the beginning of dilution before freezing. Circular motility of the cryopreserved spermatozoa indicates exposure of spermatozoa for premature capacitation, hyperactivity and acrosome reaction (El-Shahat et al. (2016). Induction of hyperactivity and acrosomal reaction prior to freezing may be the main cause of lowered sperm viability with L- arginine addition for long time, from the beginning of dilution before freezing, before freezing recorded in the present study.

Meanwhile, addition of $0.5 \mathrm{mM}$ of Larginine after $2 \mathrm{~h}$ equilibration and just before filling of straws, short time exposure, improved semen motility, viability, and fertilizing ability, but maintained the acrosomal integrity compared to the control semen.

The positive effect of L-arginine on the post-thawed buffalo semen may be attributed to increase production of nitric oxide which enhances the metabolic rate, it also enhances cGMP synthesis, thus leading to increase the calcium level in the mitochondria and generating a higher adenosine triphosphate (ATP) (Sengoku et al., 1998; Revelli et al., 2001 and Maidin. et al., 2014). Moreover, it has been reported that L-arginine administrated rabbits and male goats have significant increase in sperm motility, which is thought to be associated with an increase in the rate of glycolysis, resulting in higher rates of ATP and lactate generation in spermatozoa (Schachter et al., 1973; Zini et al., 1995; Patel et al., 1998).

Additionally, nitric oxide is a reactive nitrogen species (RNS) that can act in inter and intracellular signaling, and as an antioxidant (Pacher et al., 2007). Larginine acts as an antioxidant by absorption of oxygen for cell metabolism and inactivating superoxide $\left(\mathrm{O}_{2}\right)$ anions (Brown et al., 1999), that cause peroxidative damage to membrane phospholipids. The membrane lipids of spermatozoa are highly vulnerable to the action of peroxidizing agents. The peroxides comprise a potential risk to the structural and functional integrity of spermatozoa, reducing the motility and metabolic activity of sperm cells (Lipton, 1999). Intact plasma membrane has a negative correlation with lipid peroxidation and is positively correlated with the viability and motility of spermatozoa (Chen et al., 2018).

L-arginine prevents membrane lipid peroxidation in spermatozoa under different peroxidation conditions (Srivastava et al., 2006). It has been proposed that the beneficial effects of L-arginine are linked to nitric oxide (Palmer et al., 1988), thereby decreasing lipid peroxidation (Srivastava et al., 2006) and maintaining membrane integrity (Aitken and Baker, 2013).

Lipid peroxidation stimulates mitochondria to produce excessive cytochrome- $\mathrm{c}$ that will cause apoptosis (Andrew et al., 2002), which cause a rapid decrease of sperm motility (Peterson et al., 2010). There was a correlation between apoptosis, and each of increased DNA fragmentation, and the 
lower fertilization rates of in vitro fertilization (Manente et al., 2015). These reports may emphasis the current result of improved the conception rate of cow buffaloes that inseminated with L-arginine supplemented semen.

On the other hand, the current results indicated that, regardless the time of addition, high L-arginine concentration has a drastic effect on frozen-thawed semen quality, probably by excessive generation of NO, can cause sperm toxicity as well as reduce sperm motility by contributing to the formation of peroxynitrite, a highly toxic anion of peroxidation (Levonen, et al., 2001). These results are in parallel with the results reported by El-Shahat et al. (2016) and Kaya et al. (2017). The authors found that high L-arginine concentration reduces sperm motility and adversely affects the quality of spermatozoa, that may be due to increase of L-arginine will be increase Nitric oxide (NO) concentration which have negative effect on sperm motility and are associated with increase sperm toxicity (Rosselli et al., 1995).

\section{CONCLUSION}

The emerged results of this study clearly demonstrate that supplementation of semen extender with $0.5 \mathrm{mM}$ of $\mathrm{L}$ arginine to the freezing extender after 2 $h$ equilibration (short time exposure) have valuable effects on the quality and the fertilizing potentials of the cryopreserved buffalo spermatozoa. These constructive effects appeared due to the improvement of the antioxidant activities and the diminishing rates of lipid peroxidation of the cryopreserved spermatozoa.

\section{REFERENCES}

Abd-Allah, E.A.; Salem, M.M. and Eliraqy, E.Z. (2019): Effect of addition 1-arginine to extender of poor motile Holstein bulls spermatozoa. J. Product. \& Dev., 24(1): $165-179$.

Adman, M. (1970): Effect of arginine on oligospermia. Fertil. Steril: 21:217-219.

Aitken, R.J. and Baker, M.A. (2013): Causes and consequences of apoptosis in spermatozoa: Contributions to infertility and impacts on development. Int. J. Dev. Biol., 57(2-4): 265-272.

AL-Ebady, A.S.; Hussin, S.O.; ALBadry, K.I. and Ibrahim, F.F. (2012): Effect of adding L.arinine on some parameters of bull sperms after freezing in liquid nitrogen ($196^{\circ} \mathrm{C}$ ): AL-Qadisiya. J. Vet. Med. Sci., 11,2: 156-161.

Andrew, W.D.; Hill, V.D.; Keesey, J. and Manzow, S. (2002): Cell Death Apoptosis and Necrosis Proliferation. Boehringer, Mannheim, $2^{\text {nd }}$ revised edition.

Aydin, S.; Inci, $O$. and Alagöl, B. (1995): The role of arginine, indomethacin and kallikrein in the treatment of oligospermia. Int. Urol. Nephrol., 27: 199-202.

Badr, M.R.; Mary, G. and Abd ElMalak Hassan, H.M. (2010): Effect of trehalose on cryopreservation, oxidative stress and DNA integrity of buffalo spermatozoa. J. Reproduction and infertility. 2:50-57. 
Brown, G.C. (1999): Nitric oxide and mitochondrial respiration. Biochim. Biophys. Acta., 1411:351-369.

Chemineau, P.; Cognine, Y.; Guerin, Y.; Orgeure, $P$. and Valtet, J.C. (1991): Training chromatin variations in human spermatozoa undergoing swimup and cryopreservation evaluated by the flow cytometric sperm chromatin structure assay. Mol. Hum. Reprod., 5: 29-37.

Chen, J.Q.; Li, Y.S.; Li, Z.J.; Lu, H.X.; Zhu, P.Q. and Li, C.M. (2018): Dietary L-arginine addition improves semen quality and the libido of boars under high ambient temperature. Animal, 12(8): 16111620.

El-Shahat, K.H.; Taysser, M.I.; Badr, M.R. and Zaki, K. (2016): Effect of L-arginine treatment on motility, hyperactivity, and acrosome reaction of ejaculated ram spermatozoa. Anim. Reprod., 13(2): 75-80.

El-Sheshtawy, R.I.; Sisy, G.A. and ElNattat, W.S. (2015): Effects of different concentrations of sucrose or trehalose on the post-thawing quality of cattle bull semen. Asian Pac. J. Reprod., 4: 26-31.

Hoque, MN.; Talukdar, AK.; Kamal, M.; Kumar, AJ.; Farida, YB. and Shamsuddin, M. (2011): Ovulation synchronization in water buffaloes guided by milk progesterone Elisa. J. Emb. Trans. 26:105-109.

Kaya, S.O.; Gür, S. and Kaya, E. (2017): Effect of L-arginine addition on long-term storability of ram semen. Andrologia, 50: 1-5.

Kumaresan, A.; Kadirvel, $\quad$ G.; Bujarbarbaruah, K.M.; Bardoloi, R.K.; Das, A.; Kumar, S. and Naskar, S. (2009): Preservation of boar semen at $18^{\circ} \mathrm{C}$ induced lipid peroxidation and apoptosis-like changes in spermatozoa. Anim. Reprod. Sci., 110(1-2): 162-171.

Lipton, S.A. (1999): Neuronal protection and destruction by NO. Cell Death Differ. 6:943-951.

Levonen, AL.; Patel, RP.; Brookes, P.; Go, YM.; Jo, H.; Parthasarathy, S.; Anderson, PG. and DarleyUsmar, VM. (2001): Mechanisms of cell signaling by nitric oxide and peroxynitrite: from mitochondria to 354. Comp ClinPathol, 19:351-355.

Maidin, M.S.; Adanan, N.F.; Aminudin, M.T. and Tawang, A. (2014): In vitro supplements improve motility and the progressive score of spermatozoa in Jermasia goats. APCBEE Procedia, 8: 329-333.

Manente, L.; Pecoraro, S.; Picillo, E.; Gargiulo, U.; Gargiulo, P.; De Luca, A. and Politano, L. (2015): Molecular evidence of apoptotic pathway activation in semen samples with high DNA fragmentation. In Vivo, 29(2): 289-294.

Mann, T. and Lutwak-Mann, C. (1981): In: Male reproductive function and semen. Springer-Verlag Berlin Heidelberg New York, 1:213

Medeiros, C.M.; Forell, O.; Oliveria, F. and Rodrigues, J.L. (2002): Current mediated endothelial cell 
injury. Journal of Leukocyte Biology, 64:185-191.

Moncada, S.; Palmer, R.MJ. and Higgs, E.A. (1992): Nitric oxide: physiology pathophysiology and pharmacology. Pharmacol. Rev.: 43:109-142.

O'Flaherty, C.; Rodriguez, $P$. and Srivastava, S. (2004): L-Arginine promotes capacitation and acrosome reaction in cryopreserved bovine spermatozoa. Biochim Biophys Acta., 1674:215-221.

Öztürk1, C.; Sükrü, G.; Mehmet Bozkurt, A.; Mustafa Numan, B.; Nuri, B.P. and Muhammed Enes, I. (2017): Effects of arginine and trehalose on post-thawed bovine sperm quality. Acta Veterinaria Hungarica, 65 (3): 429-439.

Pacher, P.; Beckman, JS. and Liaudet, L. (2007): Nitric oxide and peroxynitrite in health and disease. Physiol Rev., 87:315.

Palmer, RMJ.; Ashton, DS. And Moncada, S. (1988): Vascular endothelial cells synthesize nitric oxide from L-arginine. Nature, 33: 664-668.

Patel, A.B.; Srivastava, S.; Phadke, R.S. and Govil, G. (1998): Arginine activates glycolysis of goat epididymal spermatozoa: an NMR study. Biophys. J., 75: 1522-1528.

Peterson, Q.P.; Goode, D.R.; West, D.C.; Botham, R.C. and Hergenrother, P.J. (2010): Preparation of the caspase $-3 / 7$ substrate AC-DEVD-pNA by solution-phase peptide synthesis. Nat. Protoc., 5(2): 294-302.
Radany, E.W.; Atherton, R.W. and Forrester, I.T. (1981): Arginine uptake by rabbit spermatozoa. Arch. Biochem. Biophys., 210:770-774

Revelli, A.; Costamagna, C.; Moffa, F.; Aldieri, E.; Ochetti, S.; Bosia, A.; Massobrio, M.; Lindblom, B. and Ghigo, D. (2001): Signaling pathway of nitric oxide-induced acrosome reaction in human spermatozoa. Biol. Reprod.: 64:1708-1712.

Rosselli, M.; Dubey, R.K.; Imthurn, B.; Macas. E. and Keller, P.J. (1995): Effects of nitric oxide on human spermatozoa: evidence that nitric oxide decreases sperm motility and induces sperm toxicity. Hum Reprod, 10:1786-1790.

Sanocka, D. and Kurpisz, M. (2004): Reactive oxygen species and sperm cells. Reprod. Biol. Endocrinol., 23 (2):12.

Schachter, A.; Friedman, S.; Goldman, J.A. and Eckerling, B. (1973): Treatment of oligospermia with the amino acid arginine. Int. J. Gynecol. Obstet., 11: 206-209.

Sengoku, K.; Tamate, K.; Yoshida, T.; Takaoka, Y.; Miyamoto, T. and Ishikawa, M. (1998): Effects of low concentrations of nitric oxide on the zona pellucida binding ability of human spermatozoa. Fertil. Steril., 69:522-527.

Sliwa, L. and Stochmal, E. (2000): Effect of sodium nitroprusside on mouse sperm migration in vitro. Arch. Androl., 45:29-33.

Soeters, P.B.; Hallemeesch, M.M.; Bruins, M.J.; Van Eijk, H.M. and 
Deutz, N.E. (2002): Quantitative in vivo assessment of arginine utilization and nitric oxide production in endotoxemia. Am J. Surg., 183:480- 488.

Srivastava, S.; Desai, P.; Coutinho, E. and Govil, G. (2006): Mechanism of action of L-arginine on the vitality of spermatozoa is primarily through increased biosynthesis of nitric oxide. Biol Reprod., 74: 954.

Susilowati, S.; Triana, I.N.; Wurlina, W.; Arimbi, A.; Srianto, P. and
Imam Mustofa, I. (2019): Addition of L-arginine in skim milk extender maintains goat spermatozoa quality in chilled temperature for five days. Veterinary World, 12(11):17841789.

Zini, A.; De Lamirande, E. and Gagnon, C. (1995): Low levels of nitric oxide promote human sperm capacitation in vitro. J Androl., 16:424-431. 


\section{تأثثر مستوى وزمن إضافة الارجنين لمخففات السائل المنوي على قابلية التجميد وإخصاب الحيوانات المنوية للجاموس المفن المنوي}

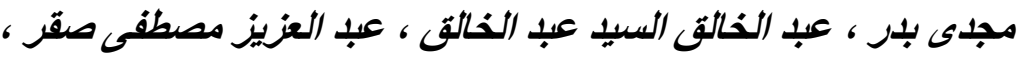

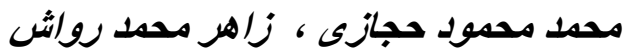

Email: mmgad2120@gmail.com Assiut University web-site: www.aun.edu.eg

الهدف من هذة الدراسة هو معرفة فائدة اضافة الارجنين الى المخفف المستخدم فى تجميد السائل المنوى وتأثثره على القابلية للتجميد و اكسدة الدهون وكفاءة الاخصاب للحيامن بعد الاذابة. تم تجميع السائل المنوى من عدد خمس طلائق بالغة مخصبة باستخدم مهبل صناعى وتم التخفيف باستخدام مخفف التريس بحيث يحتوى على تركيزات مختلفة من الارجنين (•) و (0, •) و (1)و(0) و (•) (1) مل مول/مل) تم اضافتها اثناء التخفيف أو بعد ساعتين من الموازنة. السائل المنوى المخفف تم تبريدة على درجة حر ارة 5 درجة مئوية لمدة ساعة ثم فترة مو ازنة ساعتين على درجة ؛ مئوية ثم تجميدها فى قصيبات هب , • مل قبل الحفظ فى النتروجين السائل. يتم تقدير عملية الانضاج للحيو انات المنوية بعد عملية الاذابة حيث يتم تقدير الحركة الامامية و معدل الحيوية للحيامن المجمده وسلامة

$$
\text { الاكرسوم واكسدة الدهون ومعدل الخصوبة. }
$$

النتائج الحالية بينت بوضوح أن اضافة ه ر ـ مل مول من الارجنين لمخفف السائل المنوى بعدة فترة الموازنة اظهرت

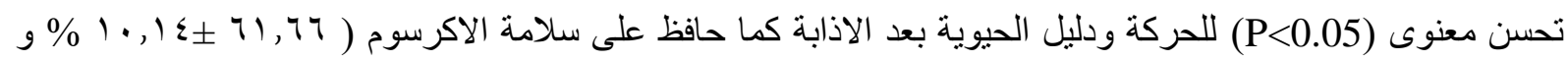
r ז, • r

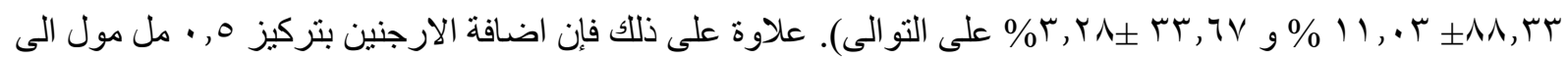

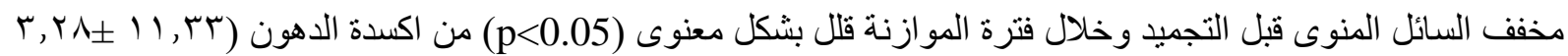

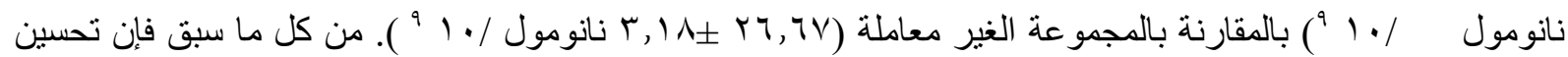
خصائص السائل المنوى بعد الاذابة ينعكس بالايجاب على القدرة الاخصابية للحيامن الموجودة بهذا السائل المنوى. النتائج الحالية أوضحت أن اضافة ه, • مل مول من الارجنين الى مخففات السائل المنوى قبل التجميد وبعد مرحلة الموازنة بساعتين (فترة قصيرة من التعرض للموازنة) ربما يحسن من صفات السائل المنوى اثثاء الحفظ وكذلك يحسن من كفاءة عملية الاخصاب لهذا السائل المنوى كما بقلل من تلف الحيامن اثناء الاسالة فى السائل المنوى لطلائق الجاموس. 